\title{
OCB Analysis, Transformational Leadership Style, Work Ethic, Work Satisfaction, And Good Governance
}

\author{
Iha Haryani Hatta ${ }^{1}$, Widarto Rachbini ${ }^{2}$, Dian Riskarini ${ }^{3}$, Yuana Rizky O. Mandagie ${ }^{4}$ \\ ${ }^{134}$ Fakultas Ekonomi dan Bisnis Universitas Pancasila, Jakarta \\ ${ }^{2}$ Sekolah Pasca Sarjana Universitas Pancasila, Jakarta \\ Email : iha.haryani@yahoo.com
}

\begin{abstract}
The existence of factors that improve employee job satisfaction will support the achievement of good governance. Therefore, study is needed on the analysis of organizational citizenship behavior (OCB), transformational leadership style, work ethic, job satisfaction, and good governance with the aim of knowing the effect of OCB, transformational leadership style, and work ethic partially on job satisfaction and good governance; the influence of job satisfaction on good governance. This study uses 200 respondents of sub-district office staff in DKI Jakarta who were selected using multistage sampling techniques. Data processing used SEM, Lisrel Program. The results showed that transformational leadership style had an effect on job satisfaction, but OCB and work ethic had no effect on job satisfaction; OCB, work ethic, and job satisfaction affect good governance, but transformational leadership style does not affect good governance.
\end{abstract}

Keywords: OCB, Transformational Leadership Style, Work Ethics, Job Satisfaction, Good Governance

\section{BACKGROUND}

One of the reform issues that has become the ideal of government stakeholders is good governance. A good government includes responsible development management in accordance with the principles of democracy and an efficient market, avoidance of misallocation of investment funds and prevention of corruption both politically and administratively in carrying out budget discipline and creating policies that support the growth of business activities. This reality for the government and the private sector in Indonesia can be the latest breakthrough in creating public credibility and reliable managerial forms. Therefore, good governance can be the basis for the creation and implementation of democratic state policies in the current era of globalization. The occurrence of a democratic phenomenon can be seen from the strengthening of public control over the administration of government. While the phenomenon of globalization can be seen from the existence of interdependence between nations, especially in the management of economic resources and business activities. Every implementer of good governance must be able to contribute in its role and duty to the achievement of the goal of state life. The government is responsible for the creation of a conducive political and legal environment and for the exercise of power (Jopinus, 2012). However, even though good governance in Indonesia has been initiated and implemented since the previous reform era, the implementation of good governance in Indonesia is still not effective even far from the ideals of reform. There are still many frauds and leaks in budget and accounting management which are the two main products of Good Governance. 
Understanding and implementing the principles of good governance have an influence on the performance of the public sector, meaning that the performance of the public sector can be optimal if it is supported by an understanding and implementation of the principles of good governance. Understanding and implementing good governance requires commitment and involvement of all parties, namely the government and society (Dwi Risnawati, 2014). The implementation of a good governance concept is needed because of dissatisfaction with the government's performance, which has been the authorities of public affairs (Neneng, 2016). Job satisfaction must be owned by someone in work. Job satisfaction is someone's attitude where his/her expectation matches with what he/she receives (Leli Nirmalasari, 2014).

Factors for achieving good governance and job satisfaction include organizational citizenship behavior (OCB), and transformational leadership style, as well as work ethic for employees. This fact is based on the results of previous studies on good governance, job satisfaction, organizational citizenship behavior (OCB), transformational leadership style, and work ethic, among others the results of studies by Renggani \& Wika (2014), Ferdinan (2015), Ramona, et al (2017), Chalida, et al (2015) and Layaman and Maya (2018) explaining that job satisfaction affects employee performance; Chamdan's (2013) study revealed that OCB affects organizational performance; study results of Royhul et al (2019) explain that transformational leadership style affects job satisfaction and organizational performance; the study results by Biatna Dulbert Tampubolon (2007) explain that the work ethic affects employee performance; the study results by Edi and Wiwik (2010) explains that OCB affects employee job satisfaction; the study results by Fairico, et al (2018) explain that OCB affects employee performance; study results by Mariman (2014) explain that OCB has an effect on improving individual performance in the public sector; study results by Titisari, et al (2016) explain that the work ethic affects the company's performance; Lusiana's (2017) study results explain that improving employee performance can contribute to the achievement of good governance; the study results by Didit, et al, (2016) explain that transformational leadership style affects job satisfaction; study results by Imam et al (2015) explains that the work ethic can increase job satisfaction. But based on previous studies there are also different relationships, among others the study results by Amilin (2016) explain that the work ethic does not affect employee performance; study results by Lusiana (2017) explain that job satisfaction does not affect work performance; study results by Beny (2013) explain that that transformational leadership style has no effect on job satisfaction.

Based on this, it is very important to conduct studies on OCB analysis, transformational leadership style, work ethic, and job satisfaction, as well as good governance with the aim of determining the level of OCB implementation, transformational leadership style, work ethic, and job satisfaction, as well as good governance in sub-district offices in DKI Jakarta; the effect of OCB, transformational leadership style, and work ethic partially on job satisfaction; the effect of OCB, transformational leadership style, and work ethic and job satisfaction partially on goodgovernance.

\section{LITERATURE REVIEW}

The variables of these studies consisted of dependent variables namely good governance, and job satisfaction. While the independent variables are OCB, transformational 
leadership style, and work ethic. Good governance is the activity of a government agency that regulates to fulfill the interests of the people and in accordance with the prevailing norms so that state ideals related to the regulation of socio-cultural, political and economic resources can be realized (Neneng, 2016). Good governance is defined as upholding the values of life in society, nation and state that are related to leadership (Jopinus, 2012). Furthermore, good governance can be realized through bureaucratic reform, eradication of corruption, collusion and nepotism $(\mathrm{KKN})$, as well as a step forward for bureaucratic reform. Bureaucratic reform, especially civil service reform, is centered on 3 (three) aspects, namely the structuring of the payroll system and social security of civil servants, the distribution of quality civil servants that are more evenly distributed between urban and rural areas, and overcoming inequality in policy formulation competencies. While efforts to eradicate KKN in Indonesia are more directed at structuring the legal system, economic system, government system, and administrative system, which does not allow for KKN practices.

In addition, a step forward for bureaucratic reform in the form of comprehensive reforms in order to fundamentally improve the performance of the bureaucracy. Meanwhile Pre-service Education and Training Class 11 of the Ministry of Religion throughout South, Central and East Kalimantan (2011) explained that good governance is a good government, meaning that government develops and implements democratic principles, legal supremacy, professionalism, accountability, transparency, excellent service, effectiveness, and efficiency can be accepted by all people. There are 7 professional attitudes of a civil servant (PNS) in good governance, namely competent and proud of his profession; trying to take responsibility; anticipatory, proactive, and initiative, not waiting for orders; trying to do excellent service and facilitate superiors and friends; want to learn a lot from those that they serve and take part in thinking and feeling their needs; strives for the smooth running of cooperation; trustworthy, honest, loyal, sincere, and open to criticism.

Job satisfaction is reflected by work morale, discipline, and work performance. High and low job satisfaction can have an unequal impact. A high level of job satisfaction will affect the achievement of effective organizational goals. Conversely, a low level of job satisfaction will be a threat that can lead to destruction or setbacks for the organization, both quickly and slowly. There are several theories of job satisfaction, among others: according to Rivai and Sagala (2010), discrepancy theory, which is a theory that measures a person's job satisfaction through the difference between something that is supposed (hope) and the reality that is perceived. If the difference value is not the same, then the condition is said to be a discrepancy. But a positive difference or something that is received more than it should be, it is a positive discrepancy; according to Rivai and Sagala (2010), equity theory, which is a theory that describes that a person will feel satisfied or not depends on the justice he receives. The main component of the equity theory is input, results, justice and injustice. A person will compare the ratio of the input of his own results to the ratio of input of results from others. If the comparison is balanced, then the person feels treated fairly so as to cause satisfaction. If the comparison is not balanced, it will cause dissatisfaction; according to Ivanchevich (1993), the two factor theory developed by Herzberg explains that these two factors are satisfied and dissatisfied. Based on extrinsic conditions, factors that cause dissatisfaction include: wages, job security, working conditions, status, company procedures, quality of supervision, and the quality of interpersonal relationships, namely co-workers, both with 
superiors, colleagues, and subordinates. Based on intrinsic conditions, factors that cause dissatisfaction include: achievement, recognition, responsibility, advancement, the work itself, dan the possibility of growth.

Meanwhile, OCB is the behavior of employees who have the ability to empathize with others and their environment, and are able to adjust the values they adopt with the values that apply to their environment (Edi and Wiwik, 2010). OCB is a voluntary behavior that can be seen, observed, and applied to organizational management, especially those related to human resources (HR). But volunteerism is only in the form of behavior and does not necessarily describe the real willingness. OCB can increase the productivity of coworkers and leaders, saves resources owned by management and the organization as a whole as well as limited energy resources for group functions. In addition, OCB can be an effective means to coordinate and enhance the activities of working groups/organizations by attracting and retaining the best employees, as well as improving the organization's ability to adapt to environmental changes. OCB consists of five dimensions including Altruism (helping coworkers to ease their burden), Courtesy (helping coworkers to prevent problems related to their work through providing consultation and information and meeting their needs), Sportsmanship (tolerance in uncomfortable situations in the work place by not complaining), Civic Virtue (engaging in activities and caring for organizational survival) and Conscientiousness (doing things that support organizational progress).

Success or failure of an agency to achieve its goals is determined by leadership. Success in leading an organization is the success of a person influencing others to implement or carry out his vision. Leadership style shows directly or indirectly about the ability of subordinates (Rivai and Ella, 2010). Meanwhile, the government leadership must be trustworthy, honorable and responsible (Koswara, 2010). A government leader should be a pioneer in all community life and governance, always trying to improve everything from ignorance to knowledge and become a light for the people. Government leadership should be the driving force for implementing good governance or implementing a clean state government (good and right governance). There are two types of leadership, namely transactional leadership and transformational leadership. The vision of transformational leaders leads their followers to work hard to achieve agreed goals (Leli, 2014). A transformational leader can change the condition of his organization by the way the leader behaves based on each stage of the transformation process. It can be said that transformational leadership can change the organization it leads to a better direction.

There are 5 dimensions including charisma or idealism, inspiration or motivation, intellectual stimulation, and individual consideration. Charisma is the leader's ability to gain pride, trust, and respect from his subordinates, as well as the ability to communicate effectively about the mission and vision of the organization that he leads. Inspirational is the leader's ability to communicate an interesting vision, using symbols to express important goals in a simple way. Intellectual stimulation is a leader behavior that encourages his subordinates to always innovate and be creative in solving problems being faced, a leader who offers new ideas so that his subordinates are motivated to rethink old ways of completing work and influencing their subordinates to view problems from a new perspective. Individualized consideration is the behavior of leaders who care about the development of their subordinates' abilities or careers, treat subordinates as individuals, and try to understand subordinates' desires and function as advisors. 
The work ethic is not only owned by individuals, but can also be owned by a group of people or community. According to Anoraga (1992), the work ethic is the view and attitude of a nation or people towards work. If community members have the attitude and view that work is a noble contribution in human life, then the work ethic of the community will tend to be high. Conversely, if members of the community view work as an activity that can be ignored for their lives, then the work ethic of the community itself will be low. High work ethic is reflected in high morale in doing things optimally, well, and with quality. In contrast for a low work ethic, according to Kusnan (2004), that community members can be said to have a high work ethic if they show the following signs: have a very positive assessment of the results of human work; placing views on work, as a very noble thing for human existence; work is perceived as a meaningful activity for human life; work is lived as a process that requires perseverance and at the same time an important means of realizing ideals; work is carried out as a form of worship. Whereas members of the community can be said to have a low work ethic as indicated by the following signs: work is perceived as a matter of self-burden; lacking and not even appreciating human work; work is seen as an obstacle in gaining pleasure; work is a form of compulsion; work is lived only as a form of life routine.

According to Lusiana (2017), work ethic is a set of basic attitudes or views held by a group of people to assess their work as a positive for improving the quality of life that affects their work behavior. The work ethic is shaped by various habits, culture, and value systems (religion and belief) which he believes. According to Sinamo (2005), there are 4 (four) pillars of the main theory about work. These four pillars are elements that sustain all types and systems of sustainable success at all levels. The four elements are referred to as Catur Darma Mahardika which means the four main dharma of success, namely: scoring achievement with superior motivation; building a future with visionary leadership; creating new value with creative innovation; improve quality with human excellence. Then the four dharma are formulated in eight aspects of the work ethic, namely: work is grace, work is a mandate; work is a call; work is self-actualization; work is worship; work is art; work is honor; work is service.

Based on the discussion above, 7 hypotheses will be tested and the study model is illustrated in Figure 1:

Hypothesis 1: OCB affects job satisfaction

Hypothesis 2: Leadership style affects job satisfaction

Hypothesis 3: Work ethic affects job satisfaction

Hypothesis 4: OCB affects Good Governance

Hypothesis 5: Leadership style affects Good Governance

Hypothesis 6: Work ethic affects Good Governance

Hypothesis 7: Job satisfaction affects Good Governance 


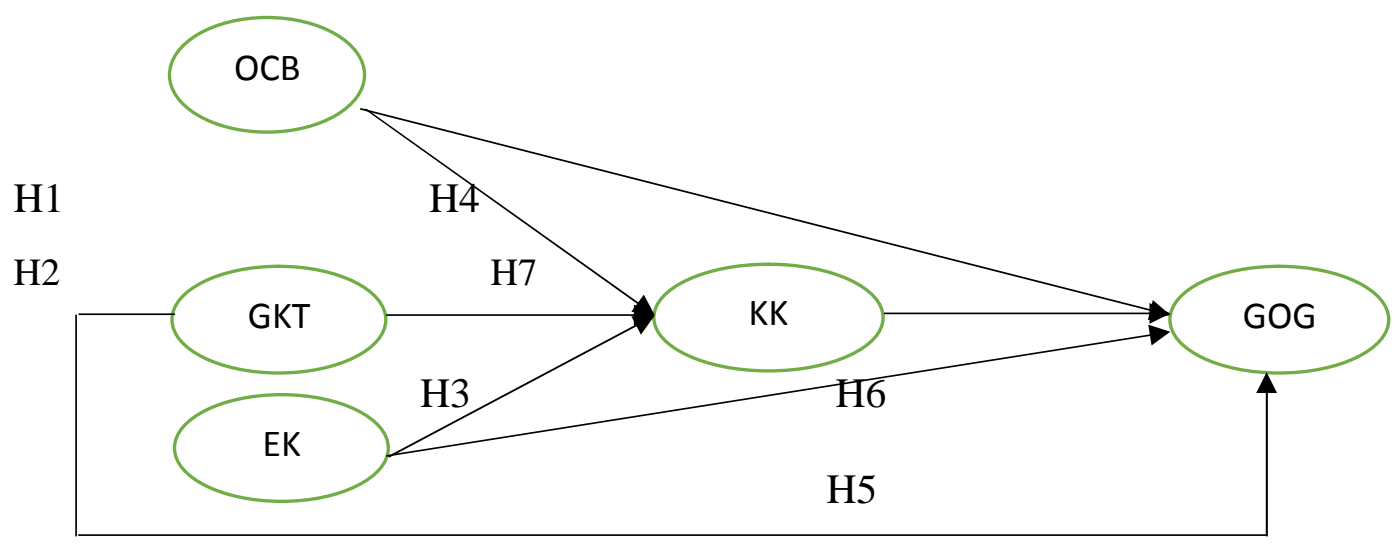

Figure 1. Study Model

\section{METHOD}

The data used is primary and secondary data. Primary data in this study was obtained from respondents' responses to a number of questions in the questionnaire. The questionnaire consists of a closed-end statement with an alternative answer according to a Likert scale. There are 5 alternative answers, namely 5 (strongly agree), 4 (agree), 3 (neutral or doubtful), 2 (disagree), 1 (strongly disagree). Meanwhile, secondary data in this study is literature study, through the search of literature related to this study such as journals, books, and documents related to theories and data related to studies.

The population in this study were employees in the sub-districts of DKI Jakarta. The sample selection technique is multistage, the first stage selected 2 random subdistricts in each area of DKI Jakarta. In the second stage, 20 employees were chosen as random respondents in the selected sub-district. So there were 10 sub-districts selected as sample units and the number of respondents were 200 employees.

Data analysis began with a test of validity and reliability. If an indicator or questionnaire item has $R$ count $>r_{\text {table, }}$, then the indicator or questionnaire item is valid, and if $\mathrm{R}_{\text {count }}<\mathrm{r}_{\text {table, }}$, then the variable is invalid. If the indicators for each variable correlate and relate to each other with a minimum $\mathrm{n}$ alpha Cronbach value of 0.6 , then the variable is said to be reliable and deserves further processing (Sugiyono, 2012).

Furthermore, the data was processed using SPSS and Structural Equation Modeling (SEM), namely the Lisrel program. From the SPSS results a descriptive analysis was carried out (Wiratna, 2015) in the form of an average value that was carried out to give an assessment on the observed variables. Assessment with the formula that (highest value (5) - lowest value (1)) / number of classes $(5)=0.8$. So that the score $1.00-1.80$ is very low, the score of $1.81-2.60$ is low, the score of $2.61-3.40$ is sufficient, the score of $3.41-4.20$ is high, and the score of 4, $21-5.00$ is very high. According to Setyo (2015), SEM is a structural equation model having the following criteria: there are 2 types of variables namely latent variables and observed variables (observed or measured or manifest variables); there are 2 types of models, namely structural models and measurement models; there are 2 types of errors, namely structural errors and measurement errors (Setyo, 2015). One covariance-based SEM program is Lisrel. Covariances show a linear relationship that occurs between two variables, namely $\mathrm{X}$ and 
Y. If a variable has a positive linear relationship, then the covariance is positive. If the relationship between $\mathrm{X}$ and $\mathrm{Y}$ is opposite, the covariance is negative. If there is no relationship between two variables $\mathrm{X}$ and $\mathrm{Y}$, the covariance is zero. From Lisrel, it can be obtained reliability, validity and t-test results. Variables are said to be reliable when construct reliability $(\mathrm{CR}) \geq 0.70$ and variance extracted $(\mathrm{VE})$ value $\geq 0.50$. The indicator of the variable is said to be valid, if the value of Standardized Loading Factor (SLF) $\geq$ 0.50 . Whereas if $\mathrm{t}$ counts $>1.96$ with a $\mathrm{p}$ value of $* * *(0.000)<0.05$, then the hypothesis is rejected. This means that there is influence between 2 variables. The opposite is true (Sofyan, 2014).

\section{THE RESULTS OF DATA PROCESSING}

The respondents of this study were 200 employees who served in North Jakarta (Kecamatan Cilincing and Pademangan), South Jakarta (Kecamatan Pasar Minggu and Pancoran), West Jakarta (Kecamatan Slipi and Palmerah), Central Jakarta (Keamatan Menteng and Tanah Abang), and East Jakarta (Kecamatan Cakung and Duren Sawit). Characteristics of respondents, among others, most respondents $(55 \%)$ were 45 years and under, male $(57 \%)$, mostly have undergraduate degrees $(61 \%)$.

The data processing results show that the organizational citizenship behavior variable consists of 10 indicators including 4 valid indicators (the indicator has a loading factor 20.60 ), which is always ready to help co-workers who need help, always ready to help new colleagues to adapt, often come early to the office, always complete the work on time. Transformational leadership style variables consist of 9 indicators including 5 valid indicators, namely the leader is able to drive individuals and groups towards the achievement of the mission, the leader provides motivation to employees morale, the leader always communicates with employees about expectations, the leader always motivates employees to think innovatively, and the leader pays attention to the availability of adequate facilities and infrastructure to support the work of their employees.

The work ethic variables consist of 7 indicators, including 4 valid indicators, namely having a high discipline in working, respecting time in work, working more productively, and always producing good work.

Job satisfaction variables consist of 10 indicators, including 8 valid indicators, namely the opportunity to do diverse jobs, capable of implementing consistent sub-district policies in daily practice, superiors can become role models in carrying out work, there are promotional opportunities if I have good performance, employees have the opportunity to do work that optimizes all their abilities, compensation received in accordance with the workload, compensation can provide certainty of the future, and compensation in accordance with my expectations.

Good governance variables consist of 10 indicators, including 8 valid indicators, namely employees always know clearly their duties, functions and authority, always take the initiative to compile a Performance Accountability Report at the end of each fiscal year, the existence of an open organizational communication system in service to the community, always disseminating programs and policies to the community, strict action against both employees and leaders who violate, fairness in determining sanctions for both leaders and employees who violate regulations, actively respond to community needs, and never differentiate gender in employment positions. 
The level of implementation at the sub-district office in DKI Jakarta about the OCB variable, transformational leadership style, work ethic, job satisfaction, and good governance is good, which means $\mathrm{OCB}=3.35, \mathrm{GKT}=3.78, \mathrm{ETK}=2.92, \mathrm{KKJ}=4.19$, and $\mathrm{GOG}=4.19$. The average value in this study variable is between 3.41 to 4.20 .

The results of data processing with Structural Equation Model (SEM), Lisrel program, obtained a study model consisting of 2 equations, namely equation with the job satisfaction variable, which consists of the OCB variable, transformational leadership style, and ETK. Another equation with the GOG variable consists of job satisfaction variable, OCB, transformational leadership style, and work ethic.

Table 1. Study Model

\begin{tabular}{ccc}
\hline No. & Structural Equation & Description \\
\hline 1. & $\mathrm{KKJ}=0.043 * \mathrm{OCB}+0.57 * \mathrm{GKT}-0.19 * \mathrm{ETK}$ & $\mathrm{R}^{2}=0.25$ \\
2. & $\mathrm{GOG}=0.41 * \mathrm{KKJ}+0.38 * \mathrm{OCB}-0.11 * \mathrm{GKT}+0.28 * \mathrm{ETK}$ & $\mathrm{R}^{2}=0.55$ \\
\hline
\end{tabular}

Source: The results of data processing

From Table 1 shows that equation 1 indicates the OCB variable, transformational leadership style, and work ethic can contribute to the job satisfaction variable by $25 \%\left(\mathrm{R}^{2}\right.$ $=0.25)$. Other variables that are not discussed in this study contribute to the job satisfaction variable of $75 \%$. Equation 2, shows that the variables of job satisfaction, OCB, transformational leadership style, and work ethic are able to contribute to good governance variable by $55 \%\left(\mathrm{R}^{2}=0.55\right)$. Other variables not discussed in this study contribute to good governance variable by $45 \%$.

Table 2. Goodness of Fit Statistics (GoF)

\begin{tabular}{|c|c|c|c|}
\hline No. & Element & Standard & Description \\
\hline 1 & $\begin{array}{l}\text { Minimum Fit Function Chi-Square }= \\
950.11(\mathrm{P}=0.0)\end{array}$ & $948.70(\mathrm{P}=0.0)$ & Not good \\
\hline 2 & $\begin{array}{l}\text { Estimated Non-centrality Parameter } \\
(\mathrm{NCP})=581.70\end{array}$ & $(494.49 ; 676.56)$ & Acceptable \\
\hline 3 & $\begin{array}{l}\text { Population Discrepancy Function Value } \\
(\text { FO) }=2.34\end{array}$ & $(1.99 ; 2.72)$ & Acceptable \\
\hline 4 & $\begin{array}{l}\text { Root Mean Square Error of Approximation } \\
(\text { RMSEA })=0.80\end{array}$ & $(0.074 ; 0.086)$ & Acceptable \\
\hline 5 & $\begin{array}{l}\text { Expected Cross-Validation Index }(E C V I)= \\
4.36\end{array}$ & $(4.01 ; 4.74)$ & Acceptable \\
\hline 6 & AIC Model $=1084.70$ & $\begin{array}{lr}\text { Independence } & \text { AIC } \\
= & 11833.27 \\
\text { Saturated } & \text { AIC }= \\
870.00 & \end{array}$ & Acceptable \\
\hline 7 & AIC Model $=1392.16$ & $\begin{array}{l}\text { Independence } \\
\text { CAIC = } 11964.40 \\
\text { Saturated CAIC } \\
=2836.84\end{array}$ & Not good \\
\hline 8 & $\begin{array}{l}\text { Parsimony Normed Fit Index (PNFI) } \\
=0.83\end{array}$ & $\begin{array}{l}\text { Normed Fit Index } \\
(\mathrm{NFI})=0.92\end{array}$ & Good \\
\hline 9 & Comparative Fit Index $(\mathrm{CFI})=0.95$ & $\begin{array}{l}\text { Non-Normed Fit } \\
\text { Index }(\mathrm{NNFI})=\end{array}$ & Not good \\
\hline
\end{tabular}


0.94

\begin{tabular}{|c|c|c|c|}
\hline 10 & Incremental Fit Index $(\mathrm{IFI})=0.95$ & & Not good \\
\hline 11 & Relative Fit Index $(\mathrm{RFI})=0.91$ & & Good \\
\hline 12 & Root Mean Square Residual $(\mathrm{RMR})=0.054$ & 0.079 & Good \\
\hline 13 & $\begin{array}{l}\text { Adjusted Goodness of Fit Index (AGFI) }= \\
0.75\end{array}$ & $\begin{array}{l}\text { Goodness of Fit } \\
\text { Index }(\mathrm{GFI})=0.79\end{array}$ & Good \\
\hline 14 & $\begin{array}{l}\text { Parsimony Goodness of Fit Index (PGFI) }= \\
0.67\end{array}$ & & Good \\
\hline
\end{tabular}

Source: The results of data processing

Based on the GoF test, the results are obtained that PNFI $=0.83, \mathrm{RFI}=0.91, \mathrm{RMR}=$ 0.054 , AGFI $=0.75$, PGFI $=0.67$, so that it can be said that the suitability of the study model can be seen in Table 2 above.

Discussion. The effect between variables is described in Figure 2 below. Organizational citizenship behavior (OCB) variable does not affect the job satisfaction variable. Because $t$ count $=0.37<\mathrm{t}$ table $(\alpha=0.05)=1.96$, which means reject $\mathrm{H} 1$. The diversity of indicator values in the variables of OCB and job satisfaction has not been able to provide clarity of the relationship between these variables. This is not consistent with the results of previous studies namely OCB has an effect on job satisfaction (Bongsu et al, 2017).

The transformational leadership style variable affects job satisfaction. This fact is obtained from $\mathrm{t}$ count $=4.48>\mathrm{t}$ table $(\alpha=0.05)=1.96$, which means accept H2. The diversity of indicator values in the variables of transformational leadership style and job satisfaction can provide the relationship clarity between these variables. This fact is in accordance with the results of previous studies that leadership style variable has a positive effect on job satisfaction variable (Marta and Ketut, 2015; Leli, 2014; Farisa, et al, 2014).

The work ethic variable does not affect the job satisfaction variable because $t$ count $=-1.98<\mathrm{t}$ table $(\alpha=0.05)=1.96$, which means reject $\mathrm{H} 3$. The diversity of indicator values on the work ethic and job satisfaction variables has not been able to provide the relationship clarity between these variables. This fact is not consistent with the results of previous studies which explain that the work ethic affects job satisfaction (Amilin, 2016).

OCB variable affects good governance variable because $\mathrm{t}$ count $=3.89>\mathrm{t}$ table $(\alpha=$ $0.05)=1.96$, which means Accept H4. The diversity of indicator values on OCB and job satisfaction variables has not been able to provide the relationship clarity between these variables. This is consistent with previous studies, namely OCB affects the employee performance (Bongsu et al, 2017).

Transformational leadership style variable does not affect good governance because $t$ count $=-0.97<\mathrm{t}$ table $(\alpha=0.05)=1.96$, which means reject H5. The diversity of indicator values in the variables of transformational leadership style and good governance has not been able to provide the relationship clarity between these variables. This is consistent with previous studies that transformational leadership style affects employee performance (Royhul, et al, 2016).

Work ethic variable affects good governance because $\mathrm{t}$ count $=3.39>\mathrm{t}$ table $(\alpha=$ $0.05)=1.96$, which means accept H6. The diversity of indicator values in the work ethic and good governance variables is able to provide the relationship clarity between these variables. This fact is consistent with the results of previous studies explaining that the work ethic affects employee performance (Hayati dan Indra, 2012). 
Job satisfaction variable affects good governance because $\mathrm{t}$ count $=5.29>\mathrm{t}$ table $(\alpha=0.05)=1.96$, which means accept H7. The diversity of indicator values on job satisfaction and good governance variables is able to provide the relationship clarity between these variables. This fact is consistent with the results of previous studies that job satisfaction has an effect on employee performance (Ibnu Gautama \& Muhammad Arfan, 2010; Bongsu et al, 2017)

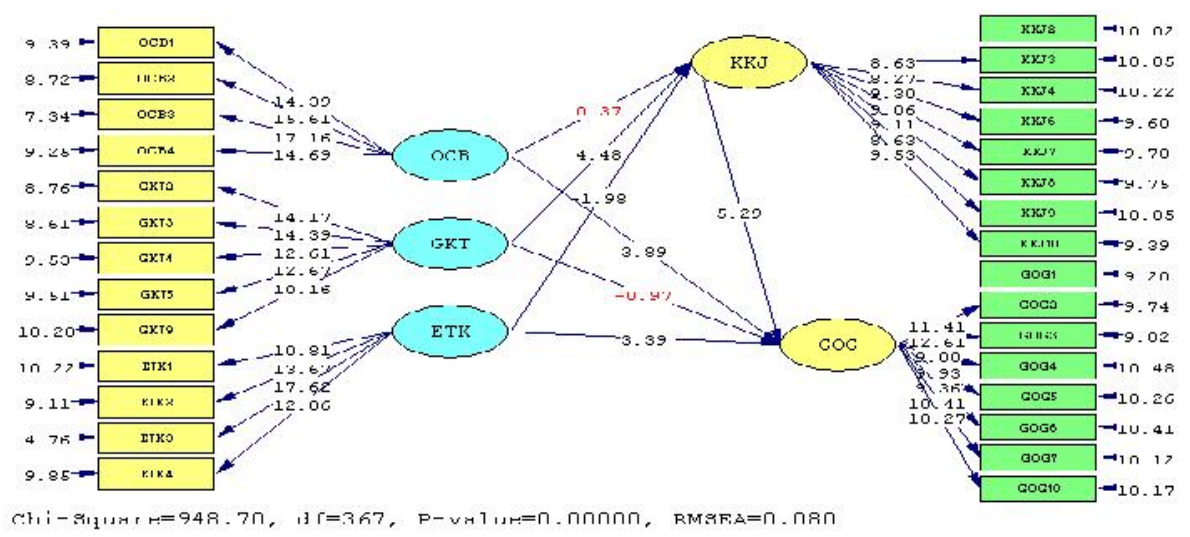

Figure 2. T Test

In Table 3 below, it can be seen that there are 3 paths in this study model, namely OCB, KKJ, GOG; GKT, KKJ, GOG; ETK, KKJ, GOG. The dominant paths are the OCB, KKJ, GOG which means that achieving good governance can be optimal, through job satisfaction supported by the implementation of OCB. 
Table 3. Direct, Indirect and Total Effect

\begin{tabular}{|c|c|c|c|c|c|c|}
\hline No. & & Lines & & Direct & Indirect & Total \\
\hline \multirow[t]{2}{*}{1.} & OCB & $\rightarrow \mathrm{GOG}$ & & 0.41 & - & - \\
\hline & OCB & $\longrightarrow \mathrm{KKJ}$ & $\longrightarrow \mathrm{GOG}$ & 0.41 & - & 0.41 \\
\hline \multirow[t]{2}{*}{2.} & GKT & $\rightarrow \mathrm{GOG}$ & & - & - & - \\
\hline & GKT & $\longrightarrow \mathrm{KKJ}$ & $\longrightarrow \mathrm{GOG}$ & - & $0.22(0.57 * 0.38)$ & 0.22 \\
\hline \multirow[t]{2}{*}{3.} & ETK & $\rightarrow$ GOG & & 0.28 & - & - \\
\hline & ETK & $\longrightarrow \mathrm{KKJ}$ & $\longrightarrow \mathrm{GOG}$ & 0.28 & - & 0.28 \\
\hline
\end{tabular}

Source: The results of data processing

The implication of this study is that achieving good governance can be optimal if it prioritizes increasing job satisfaction through the implementation of OCB. We recommend that sub-district leaders need to further improve good governance where employees always know clearly the duties and functions of their authority, always take the initiative to compile a Performance Accountability Report at the end of each fiscal year, the existence of open organizational communication system in the service to the community, always disseminate programs and policies to the community, there are decisive actions both against employees and leaders who violate, fairness in the imposition of sanctions both for leaders and employees who violate the rules, actively respond to the needs of the community, and never distinguish gender in the placement of work positions. Achievement of good governance will be optimal if it prioritizes the increase in employee job satisfaction in the form of opportunities to do diverse jobs, be able to implement consistent sub-district policies in daily practice, superiors can be role models in carrying out work, there are promotion opportunities if they have good performance, employees have the opportunity to do work that optimizes all of its capabilities, compensation received is in accordance with the workload, compensation can provide certainty of the future, and compensation is in accordance with the expectations. Increased job satisfaction can be supported by the implementation of organizational citizenship behavior in the form of employees always ready to help co-workers who need help, always ready to help new colleagues to adapt, often come early to the office, always complete the work on time.

\section{CLOSING}

The transformational leadership style variable has an effect on the job satisfaction variable, but the OCB and work ethic variables have no effect on the job satisfaction variable. OCB, work ethic, and job satisfaction variables have an effect on good governance, but transformational leadership style variable has no effect on good governance.

The achievement level of OCB activities, transformational leadership style, work ethic, job satisfaction, and good governance in the DKI Jakarta sub-district offices is good because the average value of the variables is between 3.41-4.20. This condition can be maintained even enhanced through the dominant channels, namely the OCB, KKJ, GOG 
lines. This means that increasing achievement of good governance is carried out by increasing job satisfaction by prioritizing the implementation of organizational citizenship behavior

It is expected that in further studies there will be another variable that replaces the work ethic variable as a factor supporting job satisfaction. This is needed to increase the contribution of $\left(\mathrm{R}^{2}\right)$ variables in explaining the job satisfaction variable. Considering the OCB, transformational leadership style, and work ethic variables are only able to contribute to the job satisfaction variable by $25 \%\left(\mathrm{R}^{2}=0.25\right)$, other variables that are not discussed in this study contribute to the job satisfaction variable of $75 \%$.

\section{REFERENCES}

Amilin. (2016). "Fakta Empirik Tentang Etos Kerja Islam, Stress Kerja, Kepuasan Kerja \& Kinerja Akuntan Pada Industri Keuangan Islam di Indonesia”. Jurnal Iqtishadia 9 (2), 34-325. DOI : http://dx.doi.org/10.21043/iqtishadia.v9i2.

Anoraga, Pandji. (1992). Psikologi Kerja. Jakart: Cipta

Beny Mahyudi Saputra. (2013). Pengaruh Gaya Kepemimpinan Transformasional Terhadap Kepuasan Kerja Melalui Kepercayaan Karyawan Pada Atasan. Cahaya Aktiva 03 (2), 92-100.

Biatna Dulbert Tampubolon. (2007). Analisis Faktor Gaya Kepemimpinan dan Faktor Etos Kerja Terhadap Kinerja Pegawai Pada Organisasi Yang Telah Menerapkan SNI 19-9001-2001. Jurnal Standardisasi 9 (3), 106-115.

Bongsu Saragih, Anwar Sanusi, Abdul Manan. (2017). The Influence of Job Satisfaction towards Employee Performance on The Antecedent of Competencies and Organizational Citizenship Behavior. IOSR Journal of Business and Management (IOSR-JBM) 19 (1), 21-27.

Chamdan Purnama. (2013). Influence Analysis of Organizational Culture Organizational Commitment Job and Satisfaction Organzational Citizenship Behavior (OCB) Toward Improved Organizational Performance. International Journal of Business, Humanities and Technology, 3 (5), 86-100.

Chalida Rahmi, A. Rahman Lubis, dan Amri. (2015). Pengaruh Organizational Citizenship Behavior dan Kepuasan Kerja Terhadap Kinerja pegawai dan Implikasinya Pada Kinerja Badan Pusat Statistik Kabupaten Aceh Besar \& Pidie. Journal Management Pascasarjana Universitas Syiah Kuala 4 (2), 11-19.

Didit Setyo Pambudi, Djudi Mukzam, dan Gunawan Eko Nurtjahjono. (2016). "Pengaruh Gaya Kepemimpinan Transformasional Terhadap Kinerja Karyawan Melalui Kepuasan Kerja Karyawan Sebagai Variabel Mediasi (Studi pada Karyawan PT Telkom Indonesia Witel Jatim Selatan Malang)". Jurnal Administrasi Bisnis (JAB) 39 (1), 164-171.

Diklat Prajabatan Angkatan 11 Kemenag se KalselTengTim. (2011). Good Governance (Pemerintah yang baik). Jurnalmadi.blogspot.com/24-08-2018

Dwi Risnawati. (2014). Prinsip Good Governance dalam Pelayanan Publik di Kantor Perusahaan Listrik Negara (PLN) Kecamatan Penajam Kabupaten Penajam Paser Utara. eJournal Ilmu Pemerintah 2 (1), 2279-2291.

Edi Wibowo, dan Wiwik Susilowati. (2010). "Pengaruh Kepemimpinan, Organizational Citizenship Behaviour, dan Komitmen Organisasional Terhadap Kepuasan Pegawai”. Jurnal Ekonomi dan Kewirausahaan 10 (1), 66-73. 
E. Koswara Kertapraja. (2010). Pemerintahan Daerah, Konfigurasi Politik Desentralisasi dan Otonomi Daerah Dulu, Kini, dan Tantangan Globalisasi. Jakarta: Inner.

Fairico Putra Ramadhan, Heru Susilo, Edlyn Khurotul Aini. 2018. Pengaruh Organizational Citizenship Behavior (OCB) dan Good Corporate Governance (GCG) Terhadap Kinerja Karyawan (Studi Pada Karyawan PT. TASPEN (Persero) Kantor Cabang Malang). Jurnal Administrasi Bisnis (JAB) 55 (2) Februari, 160 161.

Farisa Nuril Amaliyah, Bambang Swasto, dan Heru Susilo. (2014). "Pengaruh Gaya Kepemimpinan Transformasional Terhadap Kepuasan Kerja Dengan Motivasi Kerja Karyawan Sebagai Variabel Mediasi (Penelitian pada Karyawan PT Bank Rakyat Indonesia (Persero), Tbk, Kantor Cabang Blitar)". Jurnal Administrasi Bisnis (JAB) 14 (1), 1-8.

Ferdinan Adinoto. (2015). "Pengaruh Kepuasan Kerja, Kepemimpinan Demokratis, dan Motivasi Kerja Terhadap Kinerja Pegawai Pada Kantor Pertanahan Kabupaten Barito Timur". JSM (Jurnal Sains Manajemen), IV (2), 108-120.

Hayati, K. \& Indra, C. (2012). Islamic Work Ethic: The Role of Intrinsic Motivation, Job Satisfaction, Organizational Commitment and Job Performance. Procedia-Social and Behavioral Sciences 65, 102-110.

Ibnu Gautama dan Muhammad Arfan. (2010). "Pengaruh Kepuasan Kerja, Profesionalisme, Dan Penerapan Teknologi Informasi Terhadap Kinerja Auditor". Jurnal Telaah \& Riset Akuntansi 3 (2), 195-205.

IGN Marta Eka Putra dan Ni Ketut Sariyathi. (2015). "Pengaruh Gaya Kepemimpinan Transformasional, Lingkungan Kerja, dan Kompensasi Terhadap Kepuasan Kerja Karyawan Langgeng Laundry di Kuta, Badung”. E-Jurnal Manajemen Unud. 4 (5), 1345-1364.

Imam, A., Sattar, A. A. \& Saima, M. (2015). Employee Performance From The Lens of Islamic Work Ethics : Mediating Role of Personality X and Y. Sci, Int, (Lahore), 27 (1), 415-422.

Ivanchevich Mj and Michael T. Matterson. (1995). Organizational Behavior and Management Business. Publishing Inc. Texas.

Jopinus Saragih G. (2012). "Reformasi Aparatur Negara Untuk Melaksanakan Tata Kelola Pemerintahan Yang Baik dan Benar (Good Governance)”. Widya. 29 (319), 16-21.

Layaman dan Maya Jumalia. (2018). Pengaruh Budaya Kerja dan Etos Kerja Islami Terhadap Kinerja Karyawan Pada Bank Syariah Mandiri Cabang Cirebon. Indonesian Journal of Strategic Management 1 (1), 1-17.

Leli Nirmalasari. (2014). "Pengaruh Kepemimpinan Transformasional, Budaya Organisasi, Dan Kompensasi Terhadap Kepuasan Kerja Karyawan Pada PT Kautsar Utama Bandung”. Smart-Study \& Management Research XI (1), 53-66.

Lusiana Vega. (2017). Analisis Pengaruh Kepuasan Kerja dan Motivasi Terhadap Prestasi Kerja Pegawai dengan Etos Kerja sebagai Variabel Intervening (Studi Pada Universitas Palangka Raya). JSM (Jurnal Sains Manajemen), 1 (1,59-84.

Kusnan Ahmad. (2004). Analisis Sikap Iklim Organisasi, Etos Kerja, dan Disiplin Kerja Dalam Menentukan Efektivitas Kinerja Organisasi Di Garnizun Tetap III Surabaya. Laporan Penelitian. http://www.Damandiri.or.id/index.php/27-08-2018. 
Mariman Darto. (2014). Peran Organizational Citizenship Behavior (OCB) Dalam Peningkatan Kinerja Individu di Sektor Publik: Sebuah Analisis Teoritis dan Empiris. Jurnal Borneo Administrator 10 (1), 10-34.

Neneng Siti Maryam. (2016). Mewujudkan Good Governance Melalui Pelayanan Publik. Jurnal Ilmu Politik dan Komunikasi 6 (1), 1-18.

Ramona Octaviannand, Nurmala K. Pandjaitan, dan Sadikin Kuswanto. (2017) "Effect of Job Satisfaction and Motivation towards Employee's Performance in XYZ Shipping Company". Journal of Education and Practice 8 (8), 72-79.

Renggani Nur'aini Vidianingtyas dan Wika Harisa Putri. (2014). "Pengaruh Kompensasi, Kepuasan Kerja dan Gaya Kepemimpinan Terhadap Kinerja Karyawan Pada Perusahaan Jasa Katering Di Daerah Istimewa Yogyakarta. EFEKTIF Jurnal Bisnis dan Ekonomi 5 (1), 99-110.

Rivai Veithzal dan Ella Jauvani Sagala. (2010). Manajemen Sumber Daya Manusia Untuk Perusahaan Dari Teori ke Praktik. Jakarta: PT. Raja Grafindo Persada.

Royhul Akbar, Noermijati, dan Eka Afnan Troena. (2019). "Pengaruh Gaya Kepemimpinan Transformasional dan Stres Kerja Terhadap Kinerja Pegawai dengan Dimediasi oleh Kepuasan Kerja (Studi pada KPPN Makasar 1 dan KPPN Makasar 2)". Jurnal Aplikasi Manajemen (JAM) 14 (3), 537-545.

Setyo Hari Wijanto. (2015). Metode Penelitian menggunakan Structural Equation Modeling dengan LISREL 9. Jakarta: FEUI

Sinamo, Jansen. (2005). Delapan Etos Kerja Profesional: Navigator Anda Menuju Sukses. Bogor: Grafika Mardi Yuana

Sofyan Yamin. (2014). Rahasia Olah Data Lisrel. Jakarta: Mitra Wacana Media.

Sugiyono. (2012) M.emahami Penelitian Kualitatif. Bandung: Alfabet.

Titisari, M.Mukeri Warso, Andi Tri Haryono. (2016). Analisis Pengaruh Karakteristik Organisasi, Etos Kerja, dan Disiplin Kerja Terhadap Performa Perusahaan Dengan Efektifitas Kinerja Karyawan Sebagai Variabel Intervening (Studi Kasus pada PT Indofood Semarang). Journal of Management 2 (2), 1- 47.

V. Wiratna Sujarweni. (2015). SPSS Untuk Penelitian. Yogyakarta : Pustaka Baru Press. 